\title{
ETISK DILEMMA I DET ISLANDSKE FORRETNINGSMILJØ
}

Af sociolog Snorri Örn Árnason og professor Helgi Gunnlaugsson

Illegal and unethical behaviour by large corporations in Iceland has caused increasing concern and debate during the past few years. The main objective of this study is to examine which external and internal factors contribute to increased risk of corporate crime. The research is based on interviews with ten managers and middle managers of large corporations who were selected by snowball sampling and whose identities are hidden. The data were collected and analysed with qualitative research methods. Due to the small sample size, the results must be interpreted cautiously and the conclusions cannot be generalized. The findings show that the laws relating to business changed following the ratification of the European Economic Union in 1993, and thereupon the moral values with regard to commerce were rapidly revolutionized. Icelandic society subsequently passed through a period of conflicts of standards which created uncertainty about their implementation. This „anomic" condition increased the risk of illegal methods being used to reach corporate goals. New opportunities and greater emphasis on financial gain put increasing pressure on managers to meet these goals. Meanwhile boards of directors neglected their regulatory duties which may have contributed to an absence of counterbalance. Top management set the ethical tone, and if they select illegal means to obtain their goals it may produce an unethical organizational culture which favours and rationalizes that kind of behaviour.

\section{Indledning}

Vi oplevede gennem det 20. århundrede en massiv vækst og ekspansion hos verdens storvirksomheder. Disse mastodonter skaffer os produkter, service og job, de har indflydelse på vore forbrugsvaner og på teknificering af samfundet $i$ helhed. I takt med storvirksomhedernes øgede frihed og indflydelse er der sket en magtforskydning fra myndighederne til storvirksomhederne (Clinard og Yeager. 1980; Det islandske industri- og handelsministerium, 2004; Little, 1995).

Med forretningsmæssig indflydelse følger et stort ansvar og også en risiko for betydelig samfundsmæssig skade, hvis denne indflydelse misbruges. Krimi-

\footnotetext{
* Title in English: Ethical Dilemmas in the Icelandic Business Community. Original in Danish.
} 
nologer er generelt enige om, at økonomisk kriminalitet er blandt de alvorligste i samfundet på grund af deres virkning og omkostninger for samfundet (Clinard og Yeagar, 1980; Punch, 1996).

Emnet økonomisk kriminalitet er nærmest jomfruelig jord inden for islandsk kriminologisk forskning (Ólafsdóttir og Bragadóttir, 2006), og denne undersøgelse er den første af sin art i Island. Undersøgelsens mål var at se nøjere på, hvilke faktorer kan føre til ulovlig adfærd hos storvirksomheder.

\section{Økonomisk kriminalitet}

Den form for økonomisk kriminalitet, som vi her fokuserer på, er blevet kaldt organiseret kriminalitet og omfatter lovovertrædelser, der bliver begået af eller er resultatet af beslutninger taget af en eller flere personer i lederstillinger inden for en virksomhed. Disse beslutninger udgør overtrædelser af loven, men er i overensstemmelse med virksomhedens vedtagne målsætninger (først og fremmest optimering af udbytte), dets principper og sædvanlige arbejdsmetoder og foretages for at øge virksomhedens fortjeneste (Clinard, 1983; Pearce, 2001; Shover, 1978). Én type økonomisk kriminalitet er priskarteller, som af mange kriminologer anses for at koste samfundet højere beløb end nogen anden kriminalitetstype. Vi vil her lægge speciel vægt på at undersøge forløbene bag disse karteller, da sager af denne art tydeligt genspejler den kriminalitet, der begås af grupper af personer til fordel for virksomheder.

\section{Islandsk baggrund}

Den islandske statsmagt har fra første begyndelse spillet hovedrollen i at styre landets finansielle system. Politiske forbindelser var altafgørende angående adgangen til kapital, bl.a. gennem bankerne, der var under regeringens kontrol og styrede kapitalstrømmen i erhvervslivet (Kristinsson, Jónsson og Sveinsdóttir, 1992; Bjarnason, 2004). Restriktioner og statslig kontrol var ved magt op gennem det meste af det 20. århundrede, f. eks. inden for eksport og konkurrencepolitik. De fleste handelsprodukter var underkastet bestemmelser om prisfastsættelse (Kjartansson, 2002).

Man foretog så på kort tid gennemgribende ændringer af det islandske økonomiske system, der medførte et betydeligt åbnere handelsmiljø og med god grund kan kaldes en revolution. Ændringerne skete trinvis: lån blev indeksreguleret, der indførtes rentefrihed, uhindret valutahandel, fri bevægelse af kapital ind og ud af landet, og man oprettede et islandsk aktiemarked. Det vigtigste skridt var Islands indtræden i EØS-samarbejdet i 1993 (Kjartansson, 2002; Kristjánsson, 2001; Gylfason, 2001; Sigfússon, 2000).

Statens tilgang til erhvervslivets anliggender blev dermed en ganske anden. I stedet for politisk beslutningstagen om både stort og småt ansås det nu for sundere i videst muligt omfang at undgå statslig indgriben og lade virksomhederne 
styres af markedets kræfter og en veluddannet ledelse (Kjartansson, 2002, s. 489). Mure, der tidligere delte markederne mellem de forskellige firmaer, blev nu fjernet. Markeder, der tidligere var under statsejede virksomheders monopol, åbnedes nu, samtidigt med at banker og andre statsejede virksomheder blev solgt til private. Man har løftet restriktionerne på international handel, ikke mindst på finansmarkederne, hvilket har ført til en eksplosiv fremmarch af islandske virksomheder, blandt andet i de skandinaviske lande. Der er sket store ændringer i virksomhedssektoren vedrørende bl.a. virksomhedernes drift, samtidigt med at der gennem notering af selskaber på Islands fondsbørs er opstået en aktiekultur. Sideløbende med disse stormskridt for at øge handels- og selskabsfrihed har den islandske regering indført en ny lovgivning, der har som formål at sætte forretningslivet visse grænser. Statens indblanding i virksomhedernes drift er således ikke nødvendigvis blevet mindre, men har skiftet karakter: Den er nu mere professionel end politisk og drejer sig om tilsyn i stedet for direkte styring. Man har ophævet konkurrencerestriktioner, så en øget konkurrence nu trives på de fleste markeder. Samtidigt har lovgivning og tilsyn været i stadig udvikling (Det islandske industriog handelsministerium, 2004; Hannibalsson o.a., 2000).

Der er dog ikke blevet formet nogen fremtidspolitik, der fastlægger, hvordan enkeltpersoners rolle i alvorlige overtrædelser af konkurrenceloven skal gribes an. Dette viste sig tydeligt i foråret 2007, da olieselskabernes direktører blev frikendt af anklager for meddelagtighed i selskabernes priskartel, netop fordi loven ikke med tilstrækkelig tydelighed fastslår kriminaliteten af individets skyld. I olieselskabssagen fastlagde de tre olieselskaber bl.a. priserne på brændstof, såvel på benzinstationerne som i licitationstilbud til offentlige og private virksomheder. Selskaberne delte markedet op imellem sig og delte fortjenesten af salget på forskellig vis. I 2004 idømte Konkurrenceinstituttet olieselskaberne bøder på ISK 3,3 mia. (ca. DKK 330 mio.) for overtrædelse af konkurrenceloven gennem ca. ni år.

I 2001 benyttede Konkurrenceinstituttet sig for første gang af konkurrencelovens bødehjemmel i en sag om grøntsagshandel (Samkeppnisstofnun, 2001). Beskeden, der lå i disse store konkurrencesager, var et led i en slags vækkelse blandt offentligheden om, hvor skadelig økonomisk kriminalitet kan være for forbrugernes interesser. I løbet af de seneste 15 år er offentligheden i stigende grad blevet bevidst om dette, bl.a. på grund af en massiv behandling af forretningslivet i medierne.

I løbet af den samme periode har man bemærket en vis konflikt i kommunikationen mellem forretningsverdenen og politikere. Der er sket en magtforskydning fra politik til økonomi, og nye magtblokke med andre strukturer har afløst de ældre. Et godt eksempel på dette er en omfattende undersøgelse af Baugur Groups påståede overtrædelser af regnskabsloven, der tilsyneladende blev drevet af politiske kræfter. Baugur-sagen begyndte i 2002 og er blevet en af Islands største sager om økono- 
misk kriminalitet nogensinde. Rigspolitichefen beslaglagde dokumenter og data i virksomhedens hovedkvarterer i Island og flere andre steder. Tre år senere, i 2005, blev der rejst tiltale mod et antal nøglepersoner fra Baugur, hvor tiltalen indeholdt 40 punkter om bl.a. dokumentfalsk, regnskabssvig og underslæb. De fleste af tiltalerne, og herunder alle de alvorligste, blev afvist af retten, og tilbage står nogle få anklager mod to ansatte, som nu venter på at blive afgjort i Islands Højesteret.

Tilsyneladende er det svært for regeringen at lade være med at blande sig, hvilket utvivlsomt skal ses i lyset af den altoverskyggende indflydelse, regeringen tidligere havde på forretningslivet. Igennem de seneste år er udviklingen gået frem med stormskridt, og regeringens indgreb for at sætte klare rammer om det økonomiske miljø fremstår tøvende.

\section{Teoretisk baggrund}

Durkheims teori om anomi ved indgangen til det moderne samfund kaster lys på de forhold, der skabtes i Island under de massive og hyppige ændringer af rammerne omkring forretningslivet. Anomi betegner den tilstand, der opstår, når der ikke længere består enighed om, hvilken adfærd er acceptabel, f. eks. i overgangsperioder og ved pludselig velstandsstigning. Samfundet vil da opleve en dalende moralsk standard, hvor lovlydighed i faldende grad fungerer som rammer for samfundet. Det vil samtidigt være sværere at fastslå, hvad anses for at være afvigende adfærd (Durkheim, 1964; Giddens, 1972, 1989; Schaefer, 1986).

Durkheim fokuserede på den vedvarende risikotilstand og anomi inden for handel og advarede mod at give den stadigt voksende produktionssektor helt frie tøjler. Durkheim fastholdt, at kilden til anomien i det franske samfund mod slutningen af det 19. århundrede var den pludselige vækst $i$ industrisektoren uden en tilsvarende vækst hos de kræfter, der kunne have fastsat regler for sektoren. Ifølge Durkheim viste resultater af anomien sig som bl.a. griskhed, konkurrenceansporing, ambitioner og vægt på materielle goder og luksuriøse levemåder (Durkheim, 1964; Passas, 1995).

Mertons og ligeledes Passas' ideer får os til at tænke på, om virksomhedernes grundlæggende mål, nemlig at opnå højest muligt udbytte for sine ejere, er et uendeligt og dermed urealistisk mål og øger risikoen for anomi (Cohen, 1995; Passas, 2000; Slapper og Tombs, 1999). Mertons teoretiske model kunne anvendes på typiske forhold inden for forretningslivet på følgende måde: Hvor en virksomheds økonomiske udbytte er målestokken for dets succes, vil dets ledere udsættes for et konstant pres fra aktionærerne for at øge udbyttet. Der tages en beslutning om at bruge alle kneb for at få virksomheden til at give udbytte, og denne beslutning gøres tydelig ned gennem alle virksomhedens lederniveauer. Presset for at opnå det ønskede udbytte øger sandsynligheden for, at både ledere og medarbejdere vil benytte sig af ulovlige metoder (Cohen, 1995). 
Sutherlands teori (1983) fokuserer på kommunikationen i hver planlægningsenhed for sig. Han påstod, at den kriminelle adfærd er et produkt af socialiseringen, d.v.s. at den læres gennem kommunikation med den gruppe personer, der anser adfærden for at være positiv, men langt fra en eventuel anden gruppe, der anser adfærden for negativ. En person under de relevante forhold vil kun deltage i en sådan kriminel adfærd, hvis det positive syn vejer tungere end det negative. Det positive syn ses bl.a. i den teknik, som kriminelle ifølge Sykes og Matza anvender for at frigøre sig fra skyld. Sutherland (1983) påpegede, at der inden for virksomhedskulturen kan dannes visse sfærer, hvor ulovlig adfærd er retfærdiggjort. Det negative syn på den kriminelle adfærd i samfundet er fjerntliggende og appellerer mindre til personer i forretningsverdenens isolerede kultursfærer. Ifølge Sutherlands vurdering ville det kun med en klar modstand i samfundet mod denne kriminelle adfærd være muligt at vække disse kultursfærer til omtanke og samtidigt afværge den tilstand af anomi, der fører til dette positive syn på kriminel adfærd og retfærdiggørelsen deraf. Braithwaite (1989) støtter også dette synspunkt og peger på, hvor vigtigt det er, at initiativet til denne modstand kommer fra virksomhedernes egen medarbejderstab, og at der skabes en virksomhedskultur, der bygger på lovlydighed, samtidig med at overtrædelser af loven misbilliges (Liska og Messner, 1999).

Marshall B. Clinard (1983) foretog en epokegørende undersøgelse, der bestod af interviews med forhenværende ledere på mellemniveau hos store virksomheder. Han nåede frem til det resultat, at den største kilde til kriminel adfærd fandtes i arbejdsforløb, der fandt sted inden for virksomhederne, og kun i begrænset grad i virksomhedernes miljø. Forklaringen fandtes først og fremmest $i$ den politik, der anvendtes af virksomhedens øverste ledere, og i det alt for store pres, der blev lagt på ledere på mellemniveau. Lederne på mellemniveau anså ydre faktorer, så som virksomhedens finansielle situation eller konkurrenceposition for at have meget mindre betydning som forklaring på virksomheders kriminelle adfærd (Clinard, 1983; Gunnlaugsson, 2000). Clinards undersøgelse er forbilledet for denne undersøgelse og for den metodologi, der er anvendt.

\section{Målsætning og undersøgelsesmetoder}

Undersøgelsens hovedmålsætning er følgende: At fastslå hvilke faktorer, dels inden for hver organisation og dels i disses miljø, der er medvirkende til ulovlig adfærd hos storvirksomheder. I undersøgelsen anvendtes blandt andre følgende spørgsmål:

- Har ændringer i forretningslivets lovmæssige og politiske miljø i Island gennem de seneste år påvirket islandsk forretningsetik?

- Anlægger virksomheders ledere en politik, der fører til enten moralsk eller tvivlsom adfærd, til lovlydighed eller til overtrædelser af loven? 
- Kan et umådeholdent pres fra virksomheden eller dens øverste ledere over for lederne på mellemniveau medføre, at disse deltager i ulovlige eller tvivlsomme arbejdsmetoder?

Der blev ved indhentning af data og ved forarbejdet anvendt kvalitative undersøgelsesmetoder. Der er interviewet 10 forhenværende eller nuværende ledere på mellemniveau hos storvirksomheder i Island, der repræsenterer forskellige konkurrencebetonede sektorer i forretningslivet. Deltagerne blev bedt om at beskrive deres holdning, deres oplevelse og erfaring af de faktorer, som undersøgelsen fokuserer på. Man valgte deltagerne v.h.a. sneboldmetoden, der består i at få den første deltager til at udpege flere deltagere og disse igen til at udpege andre o.s.v. To offentligt ansatte blev ligeledes interviewet, nemlig den daværende direktør for Konkurrenceinstituttet og rådets jurist. Disse blev bedt om at belyse undersøgelsesemnet set fra myndighedernes synspunkt. Undersøgelsen baseredes yderligere på offentligt tilgængelige oplysninger, opinionsundersøgelser, mediernes behandling og andre kilder. Indsamling af materiale påbegyndtes i marts $2004 \mathrm{og}$ sluttede $\mathrm{i}$ juni 2005 med ovennævnte interview. Ved dataanalysen anvendtes induktionsmetoder, hvor man støttede sig til analysemetoder fra en underbygget teori.

Kvalitative undersøgelsesmetoder er specielt velegnede til undersøgelser af denne type, ikke mindst fordi det her drejer sig om et yderst ømtåleligt emne. Interviewmetoden skaber personlig kontakt mellem den undersøgende og deltageren og muliggør opbyggelsen af gensidig tillid. Da undersøgelsen imidlertid kun baseres på interview med en mindre og ikke repræsentativ gruppe personer, kan man ikke drage generelle slutninger af undersøgelsens resultater. Ikke desto mindre giver undersøgelsen et godt indblik i virkeligheden i den islandske forretningsverden, der hidtil har været temmelig lukket for offentlighedens øjne.

\section{Resultater: Ydre faktorer}

I deltagernes svar kom det såkaldte "grå område" i forretningsverdenen ofte på tale. Udtrykket henviser til, at man i forretningslivet accepterer en adfærd, der i samfundet generelt anses for at være på grænsen af det lovlige eller det etisk tillladelige. Dette tilkendegiver, at forretningslivet ikke alene retter sig efter de love og regler, der gælder i samfundet generelt, men også efter de spilleregler, som det sætter sig selv. Dybest set kan reglerne forstås på den måde, at man i forretningsverdenen vil gøre alt, hvad man kan komme af sted med, for at opnå sine mål. Deltagernes egne kommentarer forklarer bedst holdningen:

Der er ikke noget gråt område i loven. Det står efter min mening helt klart. Men moralsk set ved du altid, hvornår du træder ind på dette grå område. Nogle tager skridtet fuldt ud, eller i hvert fald så tæt på grænsen, som de kan, mens andre holder sig i god afstand fra grænserne. 
Selv om nogle bliver klar over, at de måske var kommet lidt ind på et gråt område, har de ikke følt, at de begik handlinger, der var dybt ulovlige. De gjorde sig måske ikke klart, hvordan Konkurrenceinstituttet eller andre tilsynsinstitutioner ville fortolke reglerne.

Denne tankegang har betydning for undersøgelsen på mange forskellige måder. For det første støtter det Sutherlands teori om, at man i forretningsverdenen finder bestemte definitioner på adfærd, der adskiller sig fra definitioner, der er mere udbredte i samfundet generelt. Det giver os grund til at tro, at den adfærd, som virksomhedens ledere på ethvert tidspunkt bifalder, defineres som regler som medarbejderne forventes at følge. For det andet er deltagernes hyppige diskussion om "det grå område" vigtig for undersøgelsens resultater, idet det antyder, at grænserne for den accepterede adfærd gennem de seneste år har været ret utydelige. Tilsyneladende finder de fleste af deltagerne, at grunden til denne usikkerhed er de nævnte gennemgribende ændringer af det lovmæssige miljø omkring den islandske forretningsverden. Ifølge deltagernes udsagn opstod der efter ændringerne en tilstand af usikkerhed, hvor gamle skikke måtte vige, og hvor forretningslivet begyndte at forme nye etiske standarder. Én deltagers kommentar bevidner dette:

Jeg tror, at ændringerne på finansmarkedet sker hurtigere, end hvad der er sundt for samfundet. Vi er her gået igennem bestemte perioder, hvor bestemte ting har været tilladt, men bliver så forbudt, og andre ting har været forbudt men bliver så tilladt. Reglerne er ikke vedtaget på samme måde som $\mathrm{i}$ andre lande.

Man kan af undersøgelsens resultater ræsonnere at tilsynsinstitutioner som Konkurrenceinstituttet har hvilet på et svagt fundament og har haft utilstrækkelig finansiering, hvorfor det ikke har været de pligter voksen, som følger sådanne institutioner. Myndigheden har været tøvende og inkonsekvent i sin fremgangsmåde over for økonomisk kriminalitet, ligesom også offentligheden har været længe om at gøre sig klart, hvad der var ved at ske inden for forretningslivet.

Undersøgelsen viser derudover, at forretningsmetoderne nu er betydeligt hårdere, end det man tidligere var vant til, og at der lægges øget vægt på hurtig profit og investeringer for ejerne i stedet for tidligere tiders principper om langtidsdrift og stabilitet i erhvervssektorerne. Efter de nye synspunkter i forretningsmiljøet pludselig begyndte at stå offentligheden klart, er der opstået konflikt om, hvilke etiske standarder man bør følge. Hvad vi har set her i Island gennem de seneste år, ligner derfor på flere måder den tilstand af anomi, som Durkheim beskriver i sine teorier. Der synes i Island ikke at have hersket nogen generel enighed om, hvad der ansås for at være anerkendt forretningspraksis, og hvad man mente var afvigelser fra denne praksis. Mens myndigheder og offentligheden på den ene side og forretningsmiljøet på den anden side har uforenelige standarder, vil der bestå høj risiko for afvigende adfærd i forretningssektoren. 


\section{Indre faktorer}

Undersøgelsens resultater antyder et stort pres på virksomhederne for at opnå deres mål. Islandske virksomheder har gennem de seneste år fokuseret betydeligt mere på udbytte og aktionærernes interesser end på at sætte klare etiske regler og vejledninger i overensstemmelse med gældende lovbestemmelser. Ligeledes synes virksomhedsledelser i mange tilfælde at have forsømt deres tilsynspligter eller at have undladt at forvisse sig om, at man i virksomhedens aktiviteter har overholdt loven.

Det fremgår af undersøgelsen, at de medarbejdere, der fungerer i et godkendt system, der har til formål at skabe fortjeneste, og som derudover sætter egne regler og etiske standarder, ikke føler, at de overtræder loven, når de arbejder hen imod virksomhedens mål. Der bør hos virksomhederne være en stærk modvægt mod ulovlig praksis i stedet for et pres for med alle midler at opnå de satte mål. Undersøgelsens deltagere var enige om, at bestyrelse og direktør former politikken hos en virksomhed og lægger linjen for dens drift. En modvægt mod kravet om profit, som ville tilskynde medarbejderne til at have loven som rettesnor, burde derfor komme fra virksomhedens øverste lederniveau og fra bestyrelsen. I et miljø, hvor ledelsen ikke er under noget tilsyn, kan lederen styre sin flok lige ind på de baner, han har lyst til, da virksomhedens arbejdsmetoder ifølge deltagernes vurdering netop først og fremmest formes af direktøren. Der er ingen tvivl, mente deltagerne, om at lederne er de personer, der tager de vigtigste beslutninger og bærer det største ansvar for virksomhedernes drift. De regler, der gælder inden for virksomheden, er sat af direktøren, der med egne handlinger og ord slår tonen an for andre medarbejdere. Disse resultater understøtter Sutherlands teori om, at en positiv kategorisering af kriminel adfærd fra direktørens side kan have en stor påvirkning på andre medarbejdere, som følger de regler, de mener gælder inden for virksomheden.

De færreste af deltagerne har personligt været udsat for, hvad der kunne kaldes umådeholdent pres fra ledernes side i deres funktion som ledere på mellemniveau, og i undersøgelsen fremkommer ikke ensidige udtalelser, der støtter teorien om, at et sådant pres kan føre til kriminel praksis hos ledere på mellemniveau. Dog sås forskellige tendenser til, at kriminel adfærd er et resultat af den atmosfære, som opstår i virksomheden og som formes af direktørens eksempel. Én deltager belyser dette meget klart i sin kommentar:

Det bliver simpelt hen til en egen verden, og hvis man hører hjemme i den verden, er man selvfølgelig selv gennemsyret af denne virkelighed. Det viser sig på den måde, at ens holdning til alle ting tages ud fra firmaets synspunkt, at alle egentlig har de samme meninger om, hvordan disse ting er, og hvordan de skal være. Holdningen over for andre firmaer, endda holdningen over for personer; det er simpelt hen et eget samfund... Der opstår en verden derinde, et separat etisk system, et samfund på bestemte områder af det daglige liv... 
Dette viser sig tydeligst i kommentarerne fra de deltagere, der kom fra olieselskaberne. Det ulovlige samarbejde mellem olieselskaberne var i deltagernes øjne en del af den kultur, som de var mere eller mindre tvunget til at være aktive deltagere i. De oplevede således presset for at løse bestemte ubehagelige opgaver, men beskrev også tavsheden over de ømtålelige emner som vanskelig. Denne tavshed kan sandsynligvis betragtes som en manifestation af pres. Gennem tavsheden sendtes den besked, at sådan foregik tingene her, og dette kunne ikke ændres. Ligeledes kom det frem i en anden deltagers kommentar, at han $\mathrm{i}$ begyndelsen havde fundet det besynderligt at møde konkurrenterne på fælles møder, men dog hurtigt havde vænnet sig til dette:

De regelmæssige møder med konkurrenterne blev ganske enkelt 'a way of life' [...]Der var naturligvis altid pres på os for at forhøje firmaets gevinstmargin. Udbyttet var meget dårligt... Og presset har selvfølgelig den virkning, at man efterhånden begynder at 'fiske' hos repræsentanterne for de andre olieselskaber: „øh.. er det ikke snart på tide at vi hæver prisen?" Der opstår en slags indirekte kultur. Det virkede ikke unaturligt at fremsætte sådanne spørgsmål.

Den holdning, der her ses hos olieselskabernes ledere på mellemniveau, passer udmærket til det case study, som Geis (1978) foretog i en meget kendt sag angående et priskartel blandt de største producenter af tungere elektrisk udstyr i USA. For at opfylde kravene fra virksomhedens ledere indgik lederne på mellemniveau hos General Electric en aftale med konkurrenterne hos Westinghouse og andre producenter af eludstyr. Forklaringen på den ulovlige praksis hos lederne på mellemniveau fandtes i det pres, de var under. Det var tilsyneladende ikke muligt at forklare den med de enkelte individers ønske om at overtræde loven. Næsten alle de anklagede var ifølge eget udsagn for nyligt indtrådt i et job, hvor ulovlig prisfastsættelse var anerkendt som forretningsmetode, og det betragtedes derfor af de anklagede som enhver anden del af arbejdet (Geis, 1978).

I virksomhedskulturens ideologi skjultes yderligere forskellige retfærdiggørelser for de aktiviteter, der blev udført. Man skød skylden på myndighederne eller på det miljø, som virksomhederne havde fungeret i. Man kan således sige, at de personer, der arbejder inden for denne kultur, ikke ser sig selv som lovovertrædere, idet de følger virksomhedens interne regler. Dette er i takt med Sutherlands (1983) ideer om, at kriminel adfærd er et resultat af en social formning i virksomhedens kultursfære.

\section{Den vigtigste lærdom af undersøgelsen}

Hvis undersøgelsens resultater har nogen betydning, så er det, at der i Island eksisterer et voksende behov for at styrke konkurrencetilsynet. Olieselskabssagen sendte et klart budskab til forretningslivet og har uden tvivl haft en stor advarende virkning. Det er dog svært at sige, hvor længe denne advarsel vil virke, og konkur- 
rencemyndighederne må derfor holde et meget vågent øje med forretningslivet. De nyligt foretagne lovændringer er muligvis epokegørende og kan, hvis alt går vel, betragtes som en ny begyndelse i konkurrencemyndighedernes arbejde og funktion. Ved sådanne ændringer kan der opstå usikkerhed om, hvilken politik konkurrencetilsynet vil vælge, og det er derfor vigtigt at fjerne al tvivl om konkurrencemyndighedernes rolle og selvstændighed. Det fremgår af deltagernes kommentarer, at Konkurrenceinstituttets politik har været præget af retshåndhævelse og ikke af præventive tiltag. Det blev også foreslået i højere grad at aktivere forretningslivet og få det ind til at samarbejde med myndighederne om at forme tilsynet og spillereglerne.

Flere juridiske teorier peger på, at et samarbejde mellem forretningsliv og myndigheder kan være en god opskrift på positive resultater i kampen mod kriminel adfærd hos virksomhederne. Braithwaite (1989) og Simpson (2002) er blandt de forskere, der mener, at de fleste virksomheder vil følge loven og selv implementere den ved hjælp af et internt tilsyn og fastsætte egne straffe ud fra dette synspunkt. Fisse og Braithwaite (1993) foreslår, at man ved udmåling af straf bør tage hensyn til dette, men at straffen bør gøres strengere i takt med virksomhedernes vilje til at begå kriminalitet. De fremlægger denne ide i et pyramideformet skema, hvor den mildeste reaktion er rådgivning, irettesættelser eller reprimander angående virksomhedernes interne tilsyn og samarbejde med myndighederne. De strengeste straffe vil derimod gå meget hårdt ud over virksomheden eller enkeltpersonen og bestå af ubetinget fængsel, fogedforbud, negativ omtale eller lukning af de skyldige virksomheder. Ideologien bag dette er, at parter, det være sig enkeltpersoner eller virksomheder, er mere tilbøjelige til at følge loven, hvis de er bevidste om, at der sideløbende med retshåndhævelsen er en straf, der vokser proportionelt med lovovertrædelsens alvorlighed. Vejledninger og spilleregler angiver, hvilke straffe man kan forvente under alle givne omstændigheder (Fisse og Braithwaite, 1993: 142).

Der opstod en livlig debat om gode ledermetoder efter udgivelsen af en rapport fra et udvalg under det islandske handelsministerium (2004). Denne debat synes dog nu at være ebbet ud. Nærværende undersøgelse rejser visse spørgsmål om, hvorvidt lovene er tilstrækkeligt tydelige omkring bestyrelsers ansvar som tilsynsførende for virksomhederne, og om denne opgave bliver udført tilfredsstillende. Det står klart, at der igen må blæses liv i debatten om etablering af et mere aktivt internt tilsyn i forretningslivet, idet det er mere hensigtsmæssigt, at forretningslivet selv tager initiativet til en overvågning af, om love og regler bliver fulgt. Man kan styrke det interne tilsyn på forskellige måder, f. eks. ved at ansætte en tilsynsførende, eller compliance officer, der indgiver rapport til bestyrelsen, sådan som det allerede er kutyme i nogle af Islands nabolande. 
Endelig er det værd at overveje, om virksomhedsledere på en tydeligere måde kunne understrege nødvendigheden af etiske regler og i et offentligt forum inspirere virksomheder til at tage et socialt ansvar. Et sådant initiativ må nødvendigvis virke stimulerende for overholdelse af loven og for hæderlig arbejdspraksis inden for handel.

\section{Efterskrift}

Det står klart, at forretningsmiljøet i Island i løbet af kort tid har gennemgået store omvæltninger, og denne udvikling har muligvis skabt situationer med øget risiko for kriminel adfærd hos virksomheder. Nye muligheder har øget virksomhedernes fokusering på udbytte og ekspansion samtidig med, at nye standarder inden for forretningsverdenen er trådt i stedet for ældre. De nye værdier karakteriseres af aggressivitet, fart og kamp om herredømme og magt. Der har tilsyneladende ikke hersket solidaritet eller enighed om etiske standarder i forretningslivet, og den deraf følgende usikkerhed om spilleregler har øget risikoen for, at virksomheder har villet tage ulovlige midler i brug for at nå sine mål. Under sådanne forhold kan de satte mål let være helt urealistiske og skabe et pres, der i højere grad end ellers ansporer medarbejdere til at anvende ufine metoder.

Direktørerne lægger linjen, og hvor tilsyn fra bestyrelsens side er minimalt, bliver kravet om profit desto større, og der opstår risiko for, at ulovlige metoder vil blive anset for at være den bedste løsning. Når et stort pres for at skabe profit kobles med usikkerhed om gældende etiske standarder, kan der hos virksomhederne opstå en kultur, der udelukkende er underkastet de love og regler, der gælder inden for virksomheden. I sådanne virksomheder er der mulighed for, at unge ledere på mellemniveau bliver delagtiggjort i kriminel praksis og lærer at retfærdiggøre ulovlige metoder og ringeagte den skade, de forårsager. Det er derfor vigtigt, at der findes en stærk modvægt til den ulovlige adfærd såvel inden for virksomheden som i dets miljø. En klar negativ modvægt hos myndighederne og offentligheden er ensbetydende med en fordømmelse af forretningsverdenen. Det bør også nævnes, at et initiativ fra storvirksomheders ledere om at tilskynde til samfundsmæssigt ansvar kan veje tungt i den offentlige debat. Et samarbejde mellem myndigheder og erhvervslivet om udformning af et klarere regelsæt er nøglen til at forhindre ulovlige forretningsmetoder eller holde dem i skak. Der hersker en tydelig mangel på undersøgelser af virksomheders kriminelle adfærd, og dette område giver mulighed for mange og vidt forskellige projekter. Hovedårsagen til denne mangel er dog sandsynligvis, at netop i undersøgelser af økonomisk kriminalitet skal kriminologer klare mange forhindringer. Forhåbentlig kan denne undersøgelse tilskynde til forskningskaben på dette område. 


\section{Litteratur:}

Bjarnason, V. (2004). Upphaf íslenskra stjórnarhátta (Islandske styreformers oprindelse). Visbending, 22(51), 29-31.

Braithwaite, J. (1989). Crime, Shame and Reintegration. Cambridge: Cambridge University Press.

Clinard, M. B. (1983). Corporate Ethics and Crime. Beverly Hills: Sage.

Clinard, M. B. og Yeager, P. C. (1980). Corporate Crime. New York: Free Press.

Cohen, D. V. (1995). Ethics and Crime in Business Firms: Organizational Culture and the Impact of Anomie. I F. Adler og W. S. Laufer (Red.), The Legacy of Anomie Theory: Advances in Criminological Theory (Vol. 6, s. 183-206). New Brunswick: Transaction Publishers.

Durkheim, E. (1964). The Division of Labour in Society. New York: Free Press.

Fisse, B. og Braithwaite, J. (1993). Corporations, Crime and Accountability. Cambridge: Cambridge University Press.

Geis, G. (1978). The Heavy Electrical Equipment Antitrust Cases of 1961. Í M. D. Ermann og R. J. Lundman (Red.), Corporate and Governmental Deviance (1.udg., s. 59-79). New York: Oxford University Press.

Giddens, A. (Red.). (1972). Emile Durkheim: Selected Writings. Cambridge: Cambridge University Press.

Giddens, A. (1989). Sociology. Cambridge: Polity Press.

Gunnlaugsson, H. (2000). Afbrot og Íslendingar (Kriminalitet og islandinge). Reykjavík: Háskólaútgáfan.

Gylfason, P. (2001). Framtiðin er annað land (Fremtiden er et andet land). Reykjavík: Háskólaútgáfan.

Hannibalsson Ó. o.a. (2000). Glefsur úr viðskiptasögu Íslands (Brudstykker fra Islands handelshistorie). Visbending, 18(51), 28-54.

Iðnaðar- og Viðskiptaráðuneyti (2004). Íslenskt viðskiptaumhverfi (Islandsk forretningsmiljø). Reykjavík: Iðnaðar- og viðskiptaráðuneyti, Upplýsingapjónusta (Det islandske industri- og handelsministeriums informationsservice).

Kjartansson, H. S. (2002). Ísland á 20. öld (Island i det 20. århundrede). Reykjavík: Sögufélag.

Kristinsson, H. J. og Sveinsdóttir, H.T. (1992). Atvinnustefna á Íslandi 1959-1991 (Arbejdspolitik i Island 1959-1991). Reykjavík: Félagsvísindastofnun Háskóla Íslands (Sociologisk Institut ved Islands Universitet).

Kristjánsson, S. (2001). Íslenska valdakerfið: Hljóðlát breyting við aldarlok (Det islandske magtsystem: En lydløs forandring ved århundredskiftet). Garðar Gíslason o.a. (Red.), Líndcela. Reykjavík: Hið íslenska bókmenntafélag.

Liska, A. E. og Messner, S. F. (1999). Perspectives on Crime and Deviance (3. udg.). New Jersey: Prentice Hall. 
Little, C. B. (1995). Deviance and Control: Theory, Research, and Social Policy (3. udg.). Itasca, Illinois: F. E. Peacock Publishers, Inc.

Ólafsdóttir, H. og Bragadóttir, R. (2006). Crime and Criminal Policy in Iceland: Criminology on the Margins of Europe. European Journal of Criminology. 3 (2): 221-253.

Passas, N. (1995). Continuities in the Anomie Tradition. Í F. Adler og W. S. Laufer (Red.), The Legacy of Anomie Theory: Advances in Criminological Theory (Bd. 6, s. 91-112). London: Transaction Publishers.

Passas, N. (2000). Global Anomie, Disnomie, and Economic Crime: Hidden

Consequences of Neoliberalism and Globalization in Russia and Around the

World. Social Justice, 27(2), 16-44.

Pearce, F. (2001). Crime and Capitalist Business Corporations. Í S. Neal og W. J.

P. (Red.), Crimes of Privilege (s. 35-48). Oxford: Oxford University Press.

Punch, M. (1996). Dirty Business. London: Sage.

Samkeppnisstofnun (Det Islandske Konkurrenceinstitut) (2001). Fréttatilkynning 3. apríl 2001 (Pressemeddelelse 3. april 2001): Samkeppnisráð sektar fyrirtæki á grænmetis- og ávaxtamarkaði fyrir ólöglegt samráð um verð og markaðsskiptingu (Konkurrencerådet idømmer firmaer på grøntsags- og frugtmarkedet bøder for ulovlig samråd om priser og markedsdeling). Hentet på sitet: www. samkeppni.is/frettatilkynningar/2001/frettatilkynning_03_04_01B.htm.

Schaefer, R. T. (1986). Sociology. New York: McGraw-Hill.

Shover, N. (1978). Defining Organizational Crime. Í M. D. Ermann og R. J. Lundman (Red.), Corporate and Governmental Deviance (1. udg., s. 37-40). New York: Oxford University Press.

Sigfússon, P. (2000). Landnám: Útrás islenskra fyrirtakja (Landvindinger: Islandske virksomheders fremmarch. Reykjavík: Fjölsýn.

Simpson, S. S. (2002). Corporate Crime, Law, and Social Control. Cambridge: University Press.

Slapper, G. og Tombs, S. (1999). Corporate Crime (1. udg.). Essex: Pearson Education Limited.

Sutherland, E. H. (1983). White-Collar Crime: The Uncut Version. New Haven: Yale University Press.

Adress:

Snorri Örn Árnason

Department of Information and Planning Reykjavik Metropolitan Police

Epost: snorri.arnason@1rh.is

Tel: +354 4441893
Helgi Gunnlaugssson

Det samfundsvidenskabelige fakultet Islands Universitet IS-101 Reykjavik Epost: helgigun@hi.is Tel: +354 5254504 